\title{
SLIPS OF THE TONGUE MADE BY THE ENGLISH STUDY PROGRAM STUDENTS
}

Tri Ayu S. Naibaho

University of Bengkulu

ayu_naibaho@yahoo.com

\section{Mazrul Aziz}

University of Bengkulu

mazrulazizma@gmail.com

Barnabas Sembiring

University of Bengkulu

barnabas_Sembiring@yahoo.com

\begin{abstract}
ABSTRAK
Tujuan dari penelitian ini adalah untuk menidentifikasi jenis salah ucapan (Slip of the Tongue) dan mengidentifikasi jenis salah ucapan yang paling dominan yang dilakukan oleh mahasiswa program studi bahasa Inggris dalam persentasi seminar proposal. Sampel dalam penelitian ini adalah 5 mahasiswa bahasa Inggris yang melakukan seminar proposal pada tanggal 23 Februari dan 27 April 2018. Rekaman dan ceklist digunakan sebagai Instrument penelitian. Pengumpulan data dilakukan dengan cara mendokumentasikan presentasi seminar proposal mahasiswa pada waktu yang telah ditentukan dan membuat transkrip rekaman tersebut. Untuk menganalisa data, metode qualitative and quantitative digunakan dalam penelitian ini. Hasil dari penelitian ini menunjukan bahwa ada 60 salah ucapan diantaranya terdapat 6 jenis salah ucapan yang timbul, antara lain; Anticipation, Perseveration, Exchange, Substitution, Addition and Deletion dan Jenis keseleo lidah yang paling banyak muncul ialah jenis Substitution.
\end{abstract}

Kata Kunci: Produksi bicara, Kesalahan Ungkapan, Salah Ucapan 


\begin{abstract}
The purpose of this research is to identify the types of slip of the tongue made by English Education Study Program students of Bengkulu University in their proposal seminar presentation and to identify the dominant type of slip of the tongue made by English Education Study Program students of Bengkulu University in their proposal seminar presentation. The samples of this study were 5 Students English Education Study Program students of Bengkulu University who carry out seminars of each student proposal on February 23rd, 2018 and on April 27th, 2018. The instrument used in this research was the writer herself. The data were collected by using documentary method. To analyze the data, the qualitative and quantitative methods were applied. The results of this research show that there are 60 data which are taken from the proposal seminar presentation of English students. In those data there are 6 of 8 types of slip of the tongue found in students' presentation; Anticipation, Perseveration, Exchange, Substitution, Addition and Deletion. The dominant type occurred was Substitution.
\end{abstract}

Key words: Speech Production, Speech Error, Slip the Tongue

\section{INTRODUCTION}

In the daily activities of human life, language plays a very important role in order to communicate with each other as social person. However, in a communication people sometimes make mistake in their utterances unconsciously. The unconscious mistakes in speaking are called speech error. People's speech is far from being perfect. Everyday speech is full of different types of speech errors, which referred as slip of the tongue. Harley (2006) argued that:

"Natural speech is full of mismatches between intention and output. Slips of the tongue are error involving the sounds or words of the language, and provide a window onto the processes of speech production."

We can see from Harley that everyone in his or her speech is potential making a slip of the tongue. The writer here is particularly interested in carrying out this kind of research due to the fact that slips of the tongue can happen to everyone. It is not only the naïve can make a mistake in speech due to slip of the tongue but also professor or expert as happened to Sigmund Freud who is be the first expert that pays attention to slips of the tongue as psychological data. He ever made a slip when he was trying to remember the name of the artist who paints the Frescos of the 'The Four Last Thing' in Orvieto Cathedral. He produces 'Botticalli', then 'Boltraffio' when the word he really wants is 'Signorelli'. According to Poulisse in Altipalmark (2014: 242) there are two criteria to operationalize the nation of slip of the tongue. The first one is that there must be an error. The second one is that the speaker must be able to repair the error. 
Atchison states that everybody's tongue slips now and again, most often when the tongue's owner is tried, a bit drunk or rather nervous (Altiparmak \& Kuruoglu, 2014). Where there is a speech, there are slips. Culter dan Henton emphasize the prevalence of the slip of the tongue in spontaneous human speech by stating that most fortunate of all, even among speech researchers, are those who study slip of the tongue (Altiparmak \& Kuruoglu, 2014).

There are eight types of slips of the tongue (Fromkin, 1971; Garrett, 1975; Shattuck-Hufnagel, 1979 cited in Carroll 2008: 193-195), namely: 1. Anticipation 2. Perseveration 3. Exchange 4. Blend 5. Shift 19 6. Substitution 7. Addition 8. Deletion. (1) Anticipation, the kind of error occurs as the appearances of sounds which come later word inappropriately appear in the first. Carroll (1986) argued that anticipations occur when a later segment takes the place of an earlier segment. For example, "Takes the places become Pakes the places", "A reading list become a leading list". (2)Perseverations, the error occurs as the appearance of sounds which is come first word inappropriately also appears in the later word. According to Carroll (1986), perseveration happens when an earlier segment replaces a later item. For example: "Waking Wabbits" for "waking rabbits". (3) Exchange, there is double shift, in which two linguistic units exchange places (Carrol, 2008: 195). For example: Fancy getting your nose [navz] remodeled [ri' modled] becomes Fancy getting your model ['modl] renosed [rınavzd]. (4) Blends/ Haplologies, a kind of slip of the tongue refers to a fusion of two words. Blends are found where the words concerned mean more or less the same thing and when either word would have been appropriate (Jaegar, 2005). For examples: Fried [fraıd] + potatoes [pa'teitars] becomes fries [frais]. (5) Shift, the addition of a linguistic unit that is deleted elsewhere. In other words, the speech unit moves to a deferent location, as in saying "she decide to hits it" instead of saying "she decides to hit it" (Carroll, 2008:195). (6) Substitutions, this type of slips occurs when a word is substituted by a different word. According to Carroll (2008), substitutions occur when one segment is replaced by an intruder. For example: "Before the place close [klaus] becomes before the place open ['aupan]. (7) Addition, the addition is an additional linguistics material such as related to phoneme, prefix and suffix, articles, prepositions, conjunctions, words, or phrases (Carrol 1986). For example: "I didn't explain this carefully [kea(r)foli] enough becomes I didn't explain this clarefully [kla(r)foli] enough. (8)Deletion, the deletions is leaving something out. According to Levelt, deletion is a unit which is missed out from the intended target (Harley, 2005). For example: "I'll just get up and mutter unintelligibly [ $\wedge$ nın'telıdzablı] becomes I'll just get up and mutter intelligibly [ın'telıdzeblı]."

Based on the fact that slips of the tongue can happen to everyone, the writer interested to carry out this study. In this study, the writer find out the types of slips of the tongue and the dominant types of slips of the tongue are made by students of English Study Program in their proposal seminar presentation based on Fromkin theory.

This study conducted on English students of Bengkulu University who did proposal seminar as a part of their Final Report. The students in presentation speech of proposal seminar certainly have 
prepared their speech well. They also have a qualified skill and knowledge to pronounce English words. However, they were in a room that is quite stressful because they do speech in front of supervisors and examiners. In that situation, the speakers were so nervous and rather panic that allows the speakers to do slips of the tongue in their presentation.

\section{METHOD}

In this research, the writer used both of qualitative and quantitative method. In the quantitative, the writer identifies the slips of the tongue and sum up the data that occurs in the presentations. In the qualitative, the writer explains and describes the data that occurs based on the types of slip of the tongue in Fromkin's theory.

According to Creswell (2009) qualitative research is a means for exploring and understanding the meaning individuals or groups ascribe to a social or human problem. This method is suitable or this research because the writer explors the phenomena in English speech production especially slips of the tongue which is found in English students' proposal seminar presentation.

The populations of this study are all of English department Students of Bengkulu University in 2017/2018 academic year who carry out seminars of each student proposal. The writer uses total sampling technique to take the sample. As Arikunto (2013) asserts that if the number of the population is less than 100 (one hundreds), the researcher should take all of the members of population as the samples of the study. The writer took all English students of Bengkulu University in
$2017 / 2018$ academic year who carry out proposal seminars on February, 23 ${ }^{\text {rd }}, 2018$.

In this research, the main instrument is the writer herself because it is impossible to analyze the data directly without any interpretation from the writer as a researcher since the data in the form of transcript of utterances. Researcher as key instrument based on Creswell (2009) qualitative researchers collect data themselves through examining documents, observing behavior, or interview participants. The writer was helped by coresearcher to maximize the reliability of this research. In collecting and analyzing the data, both researcher and co-researcher did the same procedure. After that, the result from researcher and co-researcher were compared to find the degree of agreement by using the following formula:

Coefficient of Agreement of H.J.X.

Fernandes: $\mathbf{K K}=\frac{2 S}{N 1+N 2}$

Notes : $K K>0,75=$ Reliable

$$
K K<0,75=\text { recollected the data }
$$

until the requirement was fulfilled

\section{RESULT AND DISSCUSION \\ Result}

In this research, there are 60 data which are taken from the proposal seminar presentation of English students. In those data there are 6 of 8 types of slip of the tongue found in students' presentation. The slips of the tongue found in the study were Anticipation, Perseveration, Exchange, Substitution, Addition and Deletion. Further explanation about those slips of the tongue is provided below.

Table 1. The Types of Slip of the Tongue as Made by English Student of Bengkulu University

\begin{tabular}{|c|c|c|c|c|c|c|c|c|c|}
\hline \multirow{2}{*}{ Sample } & \multicolumn{7}{|c|}{ Types of Slip of the Tongue } & \multirow{2}{*}{ Total } \\
\cline { 2 - 9 } & AT & PV & EX & $\begin{array}{c}\text { B } \\
\text { D }\end{array}$ & $\begin{array}{c}\text { S } \\
\text { H }\end{array}$ & SB & $\begin{array}{c}\text { A } \\
\text { D }\end{array}$ & DL & \\
\hline S1 & 3 & 3 & 1 & 0 & 0 & 5 & 1 & 1 & 18 \\
\hline S2 & 1 & 0 & 0 & 0 & 0 & 3 & 0 & 1 & 5 \\
\hline S3 & 0 & 0 & 1 & 0 & 0 & 4 & 1 & 3 & 9 \\
\hline S4 & 1 & 0 & 0 & 0 & 0 & 9 & 3 & 4 & 17 \\
\hline S5 & 0 & 0 & 0 & 0 & 0 & 4 & 2 & 5 & 11 \\
\hline Total & 5 & 3 & 2 & 0 & 0 & 25 & 7 & 17 & 60 \\
\hline
\end{tabular}


The table above display the frequency of slip of the tongue which made by each sample.

\section{Sample 1}

It has been shown on the table above that the student did 18 utterances contain slip of the tongue. In those data there are 6 types from 8 types of slip of the tongue was did by the student. Those types are 3 Anticipations, 3 Preservations, 1 Exchange, 5 Substitutions, 1 Additions and 5 deletions. While, Blend and Shift are not found.

Further explanation about some example slips that have occurred is provided below. (a) Anticipation, "of laws/ law study". In this utterance, the student intended to say "Law Student" became "Laws", "Preservation" the sound /S/ at the word of Laws in the pronunciation of student. In this utterance, Law is said to be the target word, and Student is said to be the origin error that is where the " $S$ " came from. (b) Perseverations, "The seek understanding of the section/ and then identifying/ unditifying/ identifying". The speaker intends to say "The seek understanding of the section/ and then identifying" but the speaker said instead "The seek understanding of the section/ and then identifying/ unditifying/ identifying". The speaker has perseveration the sound /un/ at the beginning "understanding" in the pronunciation of "identifying". In this utterance "identifying" is said to be the target word and the "understanding" is said to be the origin of the error since that is where the sound /un/ of "understanding" came after the origin. (c) Exchange, "The reason why / the research do the/the research do/ do the research/e/ because/ this is important". In this utterance, there is an exchanging between two words. The speaker utters "the reason why the research do". It should be said "The reason why do the research" (d) Substitution, "Sentences of speak/ spoken and written". There is substitution of the word that each of them has relation. The speaker intends to say "Sentences of spoken and written". In fact the speaker said the word "speak" in his statement which is has close relation and it is the verb of the intended word, in this case the word "spoken".(e) Addition, "why is it/ um/why it has to be introduction". In this utterance, we can see that the phrase "why is it/ um/why it has to be introduction", there is an additional the /is/ between the word why and it "Is". It is supposed to say the word "why it". (f)Deletion,"What about rhetoric and rhetoric/ rhetorical style". In this utterance, we can see that the phrase "what about rhetoric and rhetoric/ rhetorical style" there is a deletion occurs. In this case is deletion of the suffix "cal" in the word "rhetoric". It is supposed to say "What about rhetorical style".

\section{Sample 2.}

It has been shown on the table above that the student did 5 utterances contain slip of the tongue. In those data there are 3 types' from 8 types of slip of the tongue was did by the student. The 3 types are 1anticipation, 3 substitutions, 1 deletion, while 5 types, perseveration, exchange, blend, shift and addition are not found. (a) Anticipation, "In ret/ in literature review". In this case, the speaker intends to say "Literature review" but the speaker said instead "ret" to start word "literature". The speaker has anticipated the sound /re/ at the beginning of review in his pronunciation of literature. In this phrase "Literature" is said to be the target word, and "review" is 
said to be the origin of the error that is where the re came from. (b) Substitution, "English teacher to make/ e / to master and learn more about education strategy". In the utterance above, there are substitutions of word that each them has relation. The speaker intends to say "English teacher to master and learn more about education strategy" in the fact the speaker said the word "make" not the word "master" in the utterance which is has same group of word class. (c) Deletion, "And significant study/ significant of the study". In this utterance, we can see that the phrase "And significant study/ significant of the study" there is a deletion occurs. In this case is deletion of the preposition "of the" in the phrase "study". So, it is supposed to say "significant of the study".

Sample 3.

The sample 3 student did 9 utterances contain slip of the tongue. In those data there are 4 types' from 8 types of slip of the tongue was did by the student. The 4 types are 1 exchange, 4 substitutions, 1 addition, and 3 deletions. While 4 types, anticipation, perpetration, blend, and shift are not found. (a) Exchange, "The voyage / of the/ e/ childhood values of the Voyage of the Dawn Trader novel". In this utterance, there is an exchanging between two words. The speaker should be said "childhood values of the Voyage of the Dawn Trader novel" but the speaker put the words "The voyage" before utters "Dawn Trader novel". (b) Substitution, "What is the implications/ what are the implications". In the utterance above, there are substitutions of word that each them has relation. The speaker intends to say "what are the implications" in the fact the speaker said the word "is" not the word "are" in the utterance which is has same group of word class as a to be in the sentence. (c) Addition, "Based on the book or other researcher/ other research rom internet". In this utterance, we can see that the phrase "Based on the book or other researcher/ other research from internet" there is an addition occurs. In this case is addition of the prefix "er" in the word "research". So, it is supposed to say "based on the book or other research from internet". (d) Deletion, "To pose/ prose and poetry". In this utterance, we can see that there is a deletion when the speaker intends to say "prose and poetry". In the act the speaker say "pose" not the word prose. In this case, there is the deletion of sound $/ \mathrm{r} /$.

Sample 4

It has been shown on the table that the student did 17 utterances contain slip of the tongue. In those data there are 4 types' from 8 types of slip of the tongue was did by the student. The 4 types are 1 Anticipation, 9 Substitutions, 3 Additions and 4 Deletions, while Preservation, Exchange, Shift and Blend are not found. (a) Anticipation, "The existence the teacher eas real/ is really important". In this case, the speaker intends to say "is really important" but the speaker said instead "eas" to start word "is". The speaker has anticipation the sound /ea/ at the beginning of review in his pronunciation of is. In this phrase "is" is said to be the target word, and really is said to be the origin of the error that is where the "ea" came from. (b) Substitution, "It is not a text/ it is not a communication". In the utterance above, there are substitutions of word that each them has relation. The speaker intends to say "it is not a communication" in the fact the speaker said the word "a text" not the word "a communication" in the utterance which is has same group of word class as a noun in 
the phrase. (c) Deletion, "I will stat/ I will start my presentation". In this utterance, we can see that the phrase "I will stat" there is a deletion occurs. In this case is deletion of the sound " $r$ " in the phrase "start". So, it is supposed to say "I will start my presentation".

Sample 5.

It has been shown on the table above that the student did 11 utterances contain slip of the tongue. In those data there are 3 types' from 8 types of slip of the tongue was did by the student. The 3 types are 4 Substitutions, 2 Additions, and 5 Deletions. While 5 types, Anticipation, Preservation, exchange, blend and deletion are not found. (a) Substitution "The researcher use mis/ mix method". In the utterance above, there are substitutions of the speech unit that each them has relation. The speaker intends to say "the researcher use mix method" in the fact the speaker said the word "mis" not the word "mix" in the utterance which is has almost similar sound. (b) Addition, "Take part of souccess/ success in teaching and learning". In this utterance, we can see that the sentence "Take part of souccess/ success in teaching and learning" there is an addition occurs. In this case is addition of sound " 0 " in the phrase "success". So, it is supposed to say "Take part of success in teaching and learning". (c) Deletion, "Teacher view/ and teacher's view". We can see in the statement "/ teacher view/ and teacher's view" there is deletion occurs. In this case, there is deletion of Apostrophe $S$ in the word "teacher". Thus, it is supposed to say "Teacher's view".
Figure 1. Types of Slip of the Tongue

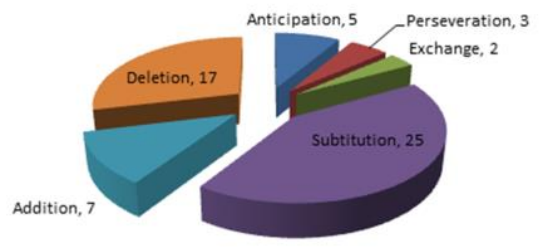

The chart above shows that the types of slip of the tongue most frequently made by students were Substitution: 25 times, Deletion: 17 times, Addition: 7 times, Anticipation: 5 times, Exchange: 2 times, and Preservation: 3 times. The writer found that Substitution was the dominant of slip of the tongue as made by students of English Study Program Department of University of Bengkulu.

\section{Discussion}

In this study, the writer took samples by using total sampling. Those samples are to all of English students of Bengkulu University who did their proposal seminar presentation on February 23rd 2018. However, in the process of collecting data, the writer got trouble with the gadget which was used as a tool to record the presentation. The writer only got 3 data from 5 students which did seminar proposal in that day. Consequently, the writer took 2 other samples in another day as the substitution. However, the writer believes that the substitution samples will not significantly influence the result of this study because the substitution samples were taken from the same population and the same situation. 
Among the samples, there was a speaker who did slips in smallest number. It was already shown in result above. Based on the writer's observation in recoding process, the speaker did presentation by memorizing delivery method of speech. Memorized delivery entails speaking from memory. Speakers with a reliable memory will be able to include specific information and engage the audience freely ("A Primer on Communication Studies", 2012). In other words, the speaker almost had no cognitive difficulty due to the speaker has memorized every words which were needed to present. It has minimized the pressure and the possibility of the speaker making a slip.

In other hands, another speaker did slips in large numbers. Based on the writer's observation in recording process, they did presentation by extemporaneous delivery method of speech which needed to select the words to explain the point of material that they have. Extemporaneous speaking often evokes higher degrees of speaking anxiety than memorizing speaking. Thus, the speakers have a lot of possibilities to make slips in their presentation.

Furthermore, in classifying the data the writer found that the speakers made 6 of 8 types of slip of the tongue. They are substitution, deletion, addition, anticipation, exchange, and preservation, while, blend and shift ware not occurred. From the finding, the writer also assumed that the appearance types of slip of the tongue are influenced by the difficulty that the speakers face during the presentation. This assumption is supported by Clark and Clark who have discovered three possible sources of planning difficulty; the cognitive difficulty, the situational anxiety and the social factors (Detrianto, 2017). In this case, the speakers have prepared themselves well. As to handle the cognitive difficulty, they have the material that they need to present, they understand it already, and they have time to prepare the material. Moreover, they were in the planned situation and they did the speech in front of their lectures and their friends who they already knew which become the solution of situational anxiety and the social factors difficulty in their speech. Those situational may cause the blend and shift types of slips of the tongue which are the complex types not occurred. In the contrary, the occurrence of the other 6 types of slips of the tongue occurred indicates that the speakers still have difficulties which are the cognitive difficulty in selecting right word to give clear explanation in their presentation, the situational anxiety in delivering their research proposal topic which is in examination process, and the social factors as a student, in the speaking which probably gives pressure to speech in front of their lecturers whose examine their presentation topic.

In this research, the substitution types appear as the dominant types that made by the English students in their proposal seminar. The dominant type found in this study is different from the previous study done by Rimawati (2009) who found that deletion is the most dominant type occurred in adults' slip and addition is the most dominant type occurred in kids' slip. Nevertheless, the Rimawati research finding is still relevant where deletion and addition are the following dominant types after substitution just like what is found in this study. Whereas, the extreme different finding of the dominant type of slip is showed in another previous study conducted by the Asyura (2017) who found that anticipation is the most dominant type made by Indonesian Comica. The writer assumes that the language used by the 
sample also influenced the appearance of the dominant type of slip. The first previous study and this study took the samples from English speech while the second previous study took the samples from speech in Bahasa Indonesia. The writer also believes that the different appearance of the dominant type of slip from those previous studies is caused by the different context and situation. The first previous study was done in English course context which has a friendly situation while the second previous study was done in competition context which has a challenging situation. However, this study was done in examination context which has pressure situation.

In examination context, however, the main purpose of the presentation done by the samples is to deliver the research proposal topic and to get the approval from the lecturers. The writer assumes that these factors may make the speaker nervous and be very careful in selecting the right words. Thus, the speakers did substitutions in many times.

\section{CONCLUSION AND SUGGESTION}

\section{Conclusion}

The result of the study shows that the entire English student made slips of the tongue in their proposal seminar presentation. The slip of the tongue consists of several types which involve anticipation, perseveration, exchange, substitution, addition, and deletion. Whereas, shift and blend were not found in all the data. The dominant type occurred was the substitution.

\section{Suggestion}

Based on the study conducted by the writer, there are some points which are expected to do by reader and future researchers. Based on the fact that slips of the tongue can occur to every people, it is expected to the reader especially English student to have a right attitude when doing the slip. The writer encourages the reader who is performing speech not to be nervous or feel bad because it will make the speaker do slips again and again. In other hands, the reader should try to avoid slips of the tongue by preparing the speech.

Furthermore, this study is descriptive qualitative study without deep analysis due to deep analysis is not need in this topic. Therefore, the future researcher is expected to explore this topic more in a different theory.

\section{REFERENCES}

Ali, Z. A. (2007). Relationship between Tongue Slip and the Field of Linguistics. Trikrit University Journal of Humanities, 14(7), 14-24.

Anonymous. 2012. A Primer on Communication Studies: Delivering a Speech (pp. 572-614). [Portable Document Format]. Retrieved from https://2012books.lardbucket.org/b ooks/a-primer-on-communicationstudies/

Arikunto, S. (2013). Prosedur Penelitian: Suatu pendekatan Praktik. Jakarta: Rineka Cipta.

Asyura, Muhammad. 2017. Pause and Slip of the Tongue on Stand Up Comedy Show in Indonesia. International EJournal of Advances in Social Sciences, 7(3), 188-196.

Atiparkmak, A. \& Kuruoglu, G. (2014). Slips of the Tongue: A Psycholinguistic 
Study in Turkish Language. Humanities and Social Sciences, 3(2), 241-254.

Carroll, David W. 2008. Psychology of Language $\left(5^{\text {th }}\right.$. ed.), USA: Thomson Higher Education.

Clark, H.H. \& Tree, J. E. F. 2002. Using Uh and Um in Spontaneous Speaking (pp. 73-111). California: Elsevier.

Creswell, John W. 2009. Research Design: Qualitative, Quantitative, and Mixed Methods Approaches (3 ${ }^{\text {rd }}$. ed.). USA: SAGE

Harley, T. A. (2005). The Psychology of Language from Data to Theory $\left(2^{\text {nd }}\right.$ Ed.). Scotland: Tylor and Francis Group.

Harley, T. A. (2006). Speech Errors: Psycholinguistic Approach. The Encyclopedia of Language and Linguistics, 2, 739-744. doi: 10.1016/BO-08-044054-2/00797-5

Kovac, Mirajana M. 2011. Speech Error in English as Foreign Language: A Case Study of Engineering Studies in Croatia. English Language and Literature Studies, 1(1), 20-39. doi: 10.5539/ells.v1n1P20

Pettinato, Michele. (2008). Infant and Child Development [Kids' Slips: What Young Children's Slip of the Tongue Reveal about Language Development by Jeri J. Jaegar]. Department of Language and Communication Sciences, 17; 302309. doi: 10.1002/icd.513

Rimawati. 2009. A psycholinguistics Analysis on Kids' and Adults' Slip of the Tongue Found in EF (English First). Malang: The State Islamic University Maulana Malik Ibrahim of Malang. 